BRAVZULIAN JOURNAL

OF MEDICAL AND BIOLOGICAL RESH.ARCH

www.bjournal.com.br
ISSN 0100-879X

Volume 44 (6) 497-605 June 2011

BIOMEDICAL SCIENCES

AND

CLINICAL INVESTIGATION

Braz J Med Biol Res, June 2011, Volume 44(6) 546-552

doi: 10.1590/S0100-879X2011007500050

Plasma cytokine response, lipid peroxidation and $\mathrm{NF}-\kappa \mathrm{B}$ activation in skeletal muscle following maximum progressive swimming

L.S. Cleto, A.F. Oleto, L.P. Sousa, T.O. Barreto, J.S. Cruz, C.L. Penaforte, J.C. Magalhães, J. Sousa-Franco, K.M.C. Pinto, A.C. Campi-Azevedo and E. Rocha-Vieira

The Brazilian Journal of Medical and Biological Research is partially financed by

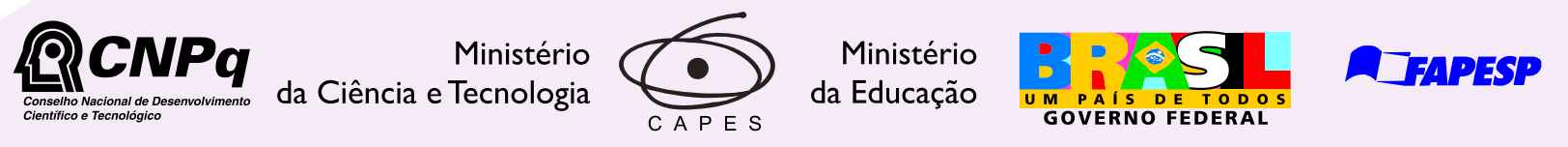

Institutional Sponsors
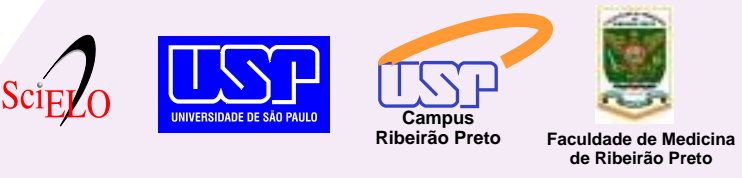

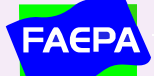

FAEPA

Ribeirão Preto 


\title{
Plasma cytokine response, lipid peroxidation and NF-kB activation in skeletal muscle following maximum progressive swimming
}

\author{
L.S. Cleto ${ }^{1}$, A.F. Oleto ${ }^{1}$, L.P. Sousa ${ }^{2}$, T.O. Barreto ${ }^{1}$, J.S. Cruz ${ }^{3}$, C.L. Penaforte ${ }^{1}$, \\ J.C. Magalhães ${ }^{4}$, J. Sousa-Franco ${ }^{1}$, K.M.C. Pinto ${ }^{5}$, A.C. Campi-Azevedo ${ }^{1,6}$ \\ and E. Rocha-Vieira ${ }^{7}$ \\ 1Departamento de Ciências Biológicas, Ambientais e da Saúde, Centro Universitário de Belo Horizonte, \\ Belo Horizonte, MG, Brasil \\ 2Departamento de Patologia, Setor de Patologia Clínica, Colégio Técnico, \\ ${ }^{3}$ Departamento de Bioquímica e Imunologia, Instituto de Ciências Biológicas, \\ Universidade Federal de Minas Gerais, Belo Horizonte, MG, Brasil \\ ${ }^{4}$ Universidade Federal de São João Del Rey, Campus Alto Paraopeba, Ouro Branco, MG, Brasil \\ ${ }^{5}$ Centro Desportivo da Universidade Federal de Ouro Preto (CEDUFOP), \\ Universidade Federal de Ouro Preto, Ouro Preto, MG, Brasil \\ 6Laboratório de Biomarcadores de Diagnóstico e Monitoração, Centro de Pesquisas René Rachou, \\ Fundação Oswaldo Cruz, Belo Horizonte, MG, Brasil \\ ${ }^{7}$ Departamento de Ciências Básicas, Universidade Federal dos Vales do Jequitinhonha e Mucuri, Diamantina, MG, Brasil
}

\begin{abstract}
Our objective was to determine lipid peroxidation and nuclear factor-kB (NF-kB) activation in skeletal muscle and the plasma cytokine profile following maximum progressive swimming. Adult male Swiss mice $(\mathrm{N}=15)$ adapted to the aquatic environment were randomly divided into three groups: immediately after exercise (EX1), $3 \mathrm{~h}$ after exercise (EX2) and control. Animals from the exercising groups swam until exhaustion, with an initial workload of $2 \%$ of body mass attached to the tail. Control mice did not perform any exercise but were kept immersed in water for 20 min. Maximum swimming led to reactive oxygen species (ROS) generation in skeletal muscle, as

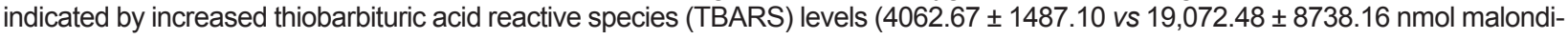
aldehyde (MDA)/mg protein, control vs EX1). Exercise also promoted NF-kB activation in soleus muscle. Cytokine secretion following exercise was marked by increased plasma interleukin-6 (IL-6) levels $3 \mathrm{~h}$ post-exercise $(\mathrm{P}<0.05)$. Interleukin-10 (IL-10) levels were reduced following exercise and remained reduced $3 \mathrm{~h}$ post-exercise $(P<0.05)$. Plasma levels of other cytokines investigated, monocyte chemotactic protein-1 (MCP-1), tumor necrosis factor-alpha (TNF- $\alpha$ ), interferon-gamma (IFN- $\gamma$ ) and interleukin-12 (IL-12), were not altered by exercise. The present findings showed that maximum swimming, as well as other exercise models, led to lipid peroxidation and NF-KB activation in skeletal muscle and increased plasma IL-6 levels. The plasma cytokine response was also marked by reduced $\mathrm{IL}-10$ levels. These results were attributed to exercise type and intensity.
\end{abstract}

Key words: Swimming; NF-kB; Interleukin-6; Interleukin-10; Thiobarbituric acid reactive species; Cytokine

\section{Introduction}

Recently, exercise has been extended from competitive sports to disease prevention and health promotion. Regular and moderate exercise has various beneficial health effects. It offers protection against all-cause mortality, primarily by protection against atherosclerosis, type 2 diabetes, colon and breast cancers (1). In addition, physical training is effective in the treatment of patients with ischemic heart disease, heart failure, and type 2 diabetes $(2,3)$.

During exercise, all physiologic systems are altered and the systemic effects of exercise result from cellular alterations promoted by each bout of exercise. Treadmill exercise has been associated with the increased generation of reactive oxygen species (ROS) in skeletal muscle $(4,5)$. Many reports also suggest that exercise-induced ROS production

Correspondence: E. Rocha-Vieira, Laboratório de Imunologia, Universidade Federal dos Vales do Jequitinhonha e Mucuri, Campus JK, Rodovia MGT367, km 583, 5000, Alto da Jacuba, 39100-000 Diamantina, MG, Brasil. Fax: +55-3138-3532-6000. E-mail: etelvieira@terra.com.br 
is responsible for the activation of signaling pathways in skeletal muscle that will culminate in cellular adaptation to exercise $(6,7)$.

Among the signaling pathways activated in response to the contractile activity of skeletal muscle, nuclear factor-kB (NF-kB) has attracted increasing attention. NF-kB dimers are sequestered basally in the cytoplasm by the inhibitor of nuclear factor-KB (I-KB). NF-KB activation involves the phosphorylation and subsequent proteolytic degradation of the inhibitory protein IKB, a process mediated by specific IkB kinases. Free NF-kB (typically, a heterodimer of p50 and $p 65$ ) then passes into the nucleus, where it binds to $\mathrm{KB}$ sites in the promoter regions of many genes, including those coding for cytokines, antioxidant enzymes, inducible nitric oxide synthase and adhesion molecules (8-10). Many signals are responsible for NF-kB activation in a variety of cells and tissues, including ROS (11-13).

Reports also demonstrate that exercise induces transitory alterations in the serum/plasma cytokine profile (14-16) marked mainly by increased serum levels of interleukin- 6 (IL-6) $(17,18)$. This change may account for the anti-inflammatory effect of exercise $(19,20)$. Evidence suggests that $\mathrm{NF}-\mathrm{KB}$ activation is responsible for the control of cytokine secretion mediated by contractile muscle (9).

Exercise responses are mainly affected by exercise type, duration and intensity. Although NF-kB activation in skeletal muscle in response to endurance exercise has been consistently demonstrated, Durham et al. (21) reported reduced NF-KB activity in human muscle following resistance exercise. It is also well documented that the cytokine response to exercise is profoundly affected by exercise type and duration, as demonstrated by Brenner et al. (22) and Peake et al. (15).

It is suggested that treadmill running is not the most effective mode of exercise for laboratory animals, especially mice, considering motivation, adaptation, duration, and exercise load control $(23,24)$. Familiarization and learning sessions are necessary for mice to adapt to treadmill running and many times mice also require aversive stimuli to run. Moreover, fatigue during running is difficult to identify in the absence of some stimuli, like electric shocks. Rodents have a natural ability to swim. Training and aversive stimuli are not necessary, and mice are motivated to avoid drowning when fatigue is imminent, assuring a high level of performance (24). Despite the advantages of using swimming as a model to study the physiologic aspects of exercise, at the present time, there is little information available on ROS generation and signaling pathways activated by the contractile activity of skeletal muscle or the plasma cytokine profile in response to swimming. In this context, the present study evaluated ROS generation and NF-KB activation in skeletal muscle, as well as the plasma cytokine response to a single bout of maximum swimming in mice. We hypothesized that swimming would result in the same pattern of ROS generation, NF-KB activation and plasma cytokine response described for other exercise types.

\section{Material and Methods}

\section{Animals and exercise protocol}

Male Swiss mice weighing $35.6 \pm 2.1 \mathrm{~g}$ at 5 to 6 weeks of age were housed in a temperature-controlled room $\left(24^{\circ} \mathrm{C}\right)$ with a 12:12-h reverse light/dark cycle. Water and standard rodent laboratory diet were supplied ad libitum. The animals were handled according to the principles outlined in the Guide for the Care and Use of Laboratory Animals (25), and experimental procedures were performed according to the standard protocol used at the Institute of Laboratory Animal Research. The procedures were approved by the Ethics Committee on Animal Experimentation of Universidade Federal de Minas Gerais (CETEA/UFMG).

Initially, animals were adapted to the aquatic environment by swimming for 10 min with no workload over the course of 5 consecutive days. Forty-eight hours after the last adaptation session, mice were submitted to a maximum progressive swimming test. Animals were randomly divided into three groups: immediately after exercise (EX1), $3 \mathrm{~h}$ after exercise (EX2) and no exercise (control). Animals swam until exhaustion with an initial workload of $2 \%$ of body mass, by the attachment of a metal hook to the animal's tail. Workloads were increased by $2 \%$ every $10 \mathrm{~min}$, without exercise interruption, by the addition of a metal ring, corresponding to $2 \%$ of mouse body mass, to the metal hook attached to the tail. Mice were weighed individually on a precision balance immediately before exercise to determine the weight of the metal loads. Exhaustion was defined as the point at which the mouse remained below the water surface for more than $4 \mathrm{~s}$. The time to exhaustion (sinking) was recorded for each mouse. Control mice did not perform any exercise but were kept immersed in water for 20 min, in contact with the tank bottom. Swimming was performed in individual bays in a glass tank $(50 \times 30 \times 25 \mathrm{~cm})$ filled with water to a height of $24 \mathrm{~cm}$ and at $30 \pm 1^{\circ} \mathrm{C}$. Animals from the EX1 and EX2 groups were euthanized immediately after and $3 \mathrm{~h}$ following exercise, respectively. Before euthanasia, blood samples were collected from the animals' tails for lactate measurement. Mice were then euthanized by cervical dislocation and a blood sample and the soleus muscle were quickly removed. Blood samples were collected into heparinized tubes and centrifuged immediately $\left(400 \mathrm{~g}, 15 \mathrm{~min}, 4^{\circ} \mathrm{C}\right)$ to separate plasma. Plasma and muscle samples were stored at $-80^{\circ} \mathrm{C}$ until the time for assay.

\section{Blood lactate measurement}

Blood lactate levels were measured using Accutrend $B M^{\circledR}$ lactate test strips (Roche, Germany) and an Accutrend ${ }^{\circledR}$ lactate portable lactate analyzer (Roche). Blood samples were obtained by making a small incision in each mouse's tail immediately after and $3 \mathrm{~h}$ following exercise. Resting values were obtained from non-exercised animals. 


\section{Detection of cytokine in blood plasma}

A BD ${ }^{\mathrm{TM}}$ Cytometric Bead Array kit (CBA, BD Biosciences, USA) was used to detect interferon-gamma (IFN-y), tumor necrosis factor-alpha (TNF- $\alpha$ ), interleukin-10 (IL-10), IL-6, interleukin-12 (IL-12p70) and monocyte chemotactic protein-1 (MCP-1) in plasma from the mice studied. Each sample $(25 \mu \mathrm{L})$ was diluted 1:5 in assay diluent. In parallel, 9-fold serial dilutions were performed with the provided standard to obtain a standard curve within the $20-5000 \mathrm{pg} /$ $\mathrm{mL}$ range. Assay diluent alone served as a negative control. Fifteen microliters of mixed cytokine capture beads was added, and the samples were incubated at $25^{\circ} \mathrm{C}$ in the dark for 90 min. Samples were washed with $500 \mu \mathrm{L}$ washing buffer and centrifuged for $7 \mathrm{~min}$ at $600 \mathrm{~g}, 18^{\circ} \mathrm{C}$. After discarding the supernatants, beads were incubated with 18 $\mu \mathrm{L}$ of mixed PE-conjugated anti-mouse cytokine antibodies at $25^{\circ} \mathrm{C}$ for another $90 \mathrm{~min}$ in the dark. Beads were washed once more, re-suspended in $250 \mu \mathrm{L}$ washing buffer and immediately analyzed using a FACScan ${ }^{\mathrm{TM}}$ flow cytometer and the CBA Analysis Software (BD Biosciences). Results are reported as $\mathrm{pg} / \mathrm{mL}$ and the lower detection limits were as follows: $5.0 \mathrm{pg} / \mathrm{mL}$ for IL-6, $17.5 \mathrm{pg} / \mathrm{mL}$ for IL-10, $52.7 \mathrm{pg} /$ $\mathrm{mL}$ for MCP-1, $2.5 \mathrm{pg} / \mathrm{mL}$ for IFN- $\mathrm{\gamma}, 7.3 \mathrm{pg} / \mathrm{mL}$ for TNF- $\alpha$, and $10.7 \mathrm{pg} / \mathrm{mL}$ for IL-12p70.

\section{Thiobarbituric acid reactive species (TBARS)}

As an index of lipid peroxidation and ROS generation in soleus muscle, we measured the formation of TBARS during an acid-heating reaction (26). Briefly, muscle samples were mixed with $1 \mathrm{~mL} 8.1 \%$ trichloroacetic acid $(2.5 \mathrm{M}$, $\mathrm{pH} 3.4$; Sigma, USA) and $1 \mathrm{~mL} 0.8 \%$ thiobarbituric acid (Sigma), and then heated in a boiling water bath for 60 min. TBARS were determined by absorbance at $532 \mathrm{~nm}$ using 1,1,3,3-tetramethoxypropane (Sigma) as an external standard. Data are reported as malondialdehyde (MDA) equivalents/mg protein.

\section{NF-KB activation in soleus muscle}

NF-KB activation was investigated by Western blotting analysis of nuclear cell extracts obtained from homogenized soleus muscle, as described previously (27). Briefly, tissue was homogenized in $1 \mathrm{~mL}$ ice-cold hypotonic lysis buffer (10 mM Tris, pH 7.4, $10 \mathrm{mM} \mathrm{NaCl}, 3 \mathrm{mM} \mathrm{MgCl} 2,0.002 \%$ $\mathrm{NaN}_{3}, 1 \mathrm{mM}$ PMSF, $0.1 \mathrm{mM}$ EGTA, $10 \mu \mathrm{M}$ aprotinin, 20 $\mu \mathrm{M}$ leupeptin, $0.5 \mathrm{mM}$ DTT, $25 \mathrm{mM} \mathrm{NaF}$ ) and chilled on ice for $15 \mathrm{~min}$ and $5 \%$ NP-40 was then added for a further $5 \mathrm{~min}$. The supernatant containing the cytosolic fraction was removed and the nuclear pellet was washed with $1 \mathrm{~mL}$ hypotonic lysis buffer to remove residual cytosolic fraction. The nuclear pellet was resuspended in $200 \mu \mathrm{L}$ high salt extraction buffer (20 mM HEPES, pH 7.4, 420 mM NaCl, 1.5 $\mathrm{mM} \mathrm{MgCl}_{2}, 0.01 \% \mathrm{NaN}_{3}, 0.2 \mathrm{mM}$ EDTA, $25 \%$ v/v glycerol, 1 mM PMSF, $10 \mu \mathrm{M}$ aprotinin, $20 \mu \mathrm{M}$ leupeptin, $0.5 \mathrm{mM}$ DTT) and incubated with shaking at $4^{\circ} \mathrm{C}$ for $30 \mathrm{~min}$. The nuclear extract was then centrifuged for $15 \mathrm{~min}$ at $13,000 \mathrm{~g}$ and the supernatant was aliquoted and stored at $-80^{\circ} \mathrm{C}$. Protein was quantified using the Bradford assay reagent from Bio-Rad (USA). Nuclear extracts $(20 \mu \mathrm{g})$ were separated by electrophoresis on a denaturing $10 \%$ polyacrylamide-SDS gel and transferred onto nitrocellulose membranes. Membranes were blocked overnight at $4^{\circ} \mathrm{C}$ with phosphate-buffered saline (PBS) containing 5\% (w/v) nonfat dry milk and $0.1 \%$ Tween-20 (Sigma-Aldrich, USA), washed three times with PBS containing $0.1 \%$ Tween-20, and then incubated with rabbit polyclonal anti-p65/RelA(C-20/sc-372; 1:1000; Santa Cruz Biotechnology, USA), in PBS containing 5\% (w/v) BSA (Sigma-Aldrich) and 0.1\% Tween-20. After washing, membranes were incubated with anti-rabbit horseradish peroxidase-conjugated secondary antibody (1:3000). Immunoreactive bands were visualized using an enhanced chemiluminescence detection system, as described by the manufacturer (GE Healthcare, USA). Nuclear levels of NF-kB p65 were quantified using the densitometric analysis software (Lablmage, Leipzig, Germany). Changes in protein levels with respect to control values were estimated and the results are reported as arbitrary units.

\section{Statistical analysis}

Statistical analyses were performed using the SPSS 12.0 software (SPSS Inc., USA). Comparisons between the three groups with respect to the mean data exhibiting parametric distribution were performed by ANOVA and comparison between two groups by the Student $t$-test. The Tukey post-test was used for multiple comparisons. TBARS levels and NF-KB activation results are reported as means \pm $\mathrm{SD}$. Plasma cytokine levels are reported as median values. Statistical significance was set at $5 \%(P<0.05)$.

\section{Results}

Blood lactate levels were $30 \%$ higher in exercised mice immediately after swimming compared to the control, nonexercised group ( $4.2 \pm 0.4$ vs $3.3 \pm 0.2 \mathrm{mM}$, EX1 vs control). Three hours after exercise, blood lactate levels were similar in the experimental and control groups (3.2 \pm 0.3 vs $3.3 \pm$ $0.2 \mathrm{mM}, \mathrm{EX} 2$ vs control group). Time to exhaustion was 21 $\pm 4 \mathrm{~min}$ and maximum overload achieved was $5.8 \pm 0.9 \%$ of body mass.

To investigate whether maximum swimming can induce oxidative stress in skeletal muscle, the levels of TBARs were measured in samples of soleus muscle from non-exercised mice (control) and from exercised mice immediately after (EX1) and $3 \mathrm{~h}$ after (EX2) exercise. Figure 1 shows a 4.7fold increase in MDA levels in skeletal muscle immediately after exercise in the experimental group (EX1) compared to control. Three hours after exercise (EX2), MDA levels returned to pre-exercise levels.

The activation of the transcription factor NF-kB in skeletal muscle following swimming was also investigated. The p65 NF-KB subunit was not observed in nuclear samples 
of soleus muscle from non-exercised mice (control). NF$\mathrm{KB}$ activation was observed in soleus muscle immediately following exercise, as indicated by the presence of the p65 subunit in nuclear samples from muscle cells (Figure 2).

Plasma cytokine levels were also evaluated in response to maximum swimming. Plasma IL-10 levels were significantly reduced immediately after and $3 \mathrm{~h}$ following

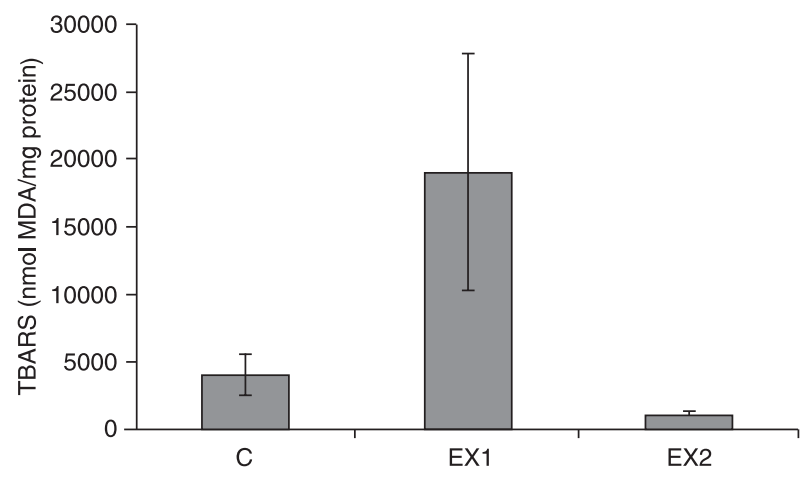

Figure 1. Skeletal muscle levels of thiobarbituric acid reactive substances (TBARS) in non-exercised control mice (C) and in exercised mice immediately after (EX1) and $3 \mathrm{~h}$ following exercise (EX2). Data are reported as means \pm SD for 5 mice per group. exercise $(P<0.05)$, whereas IL-6 levels were significantly increased $3 \mathrm{~h}$ following exercise (Figure 3 ). No effect of exercise was observed on plasma levels of IFN-Y, IL-12, MCP-1, or TNF- $\alpha$.
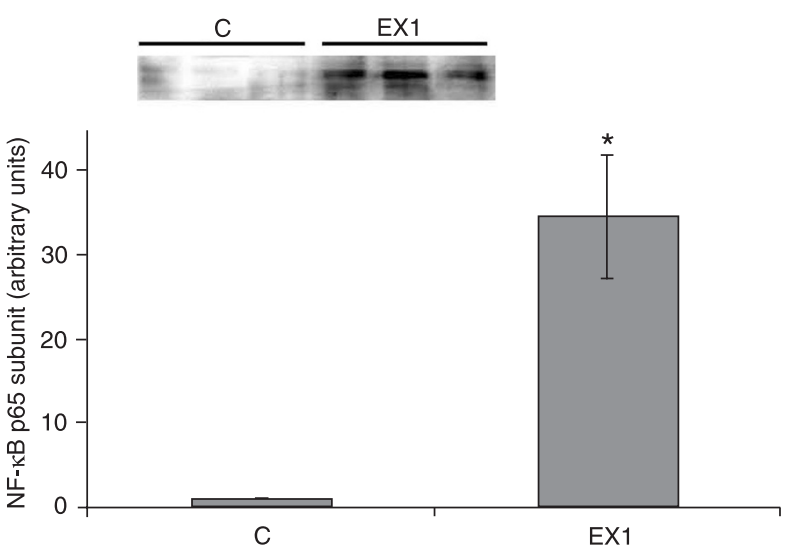

Figure 2. Levels of NF-kB p65 subunit in nuclear extracts of soleus muscle from non-exercised control mice (C) and from exercised mice immediately after swimming (EX1). Data are reported as means $\pm S D$ for 3 mice per group. ${ }^{*} P<0.05$ compared to control (Student $t$-test). The inset shows a Western blot gel image.

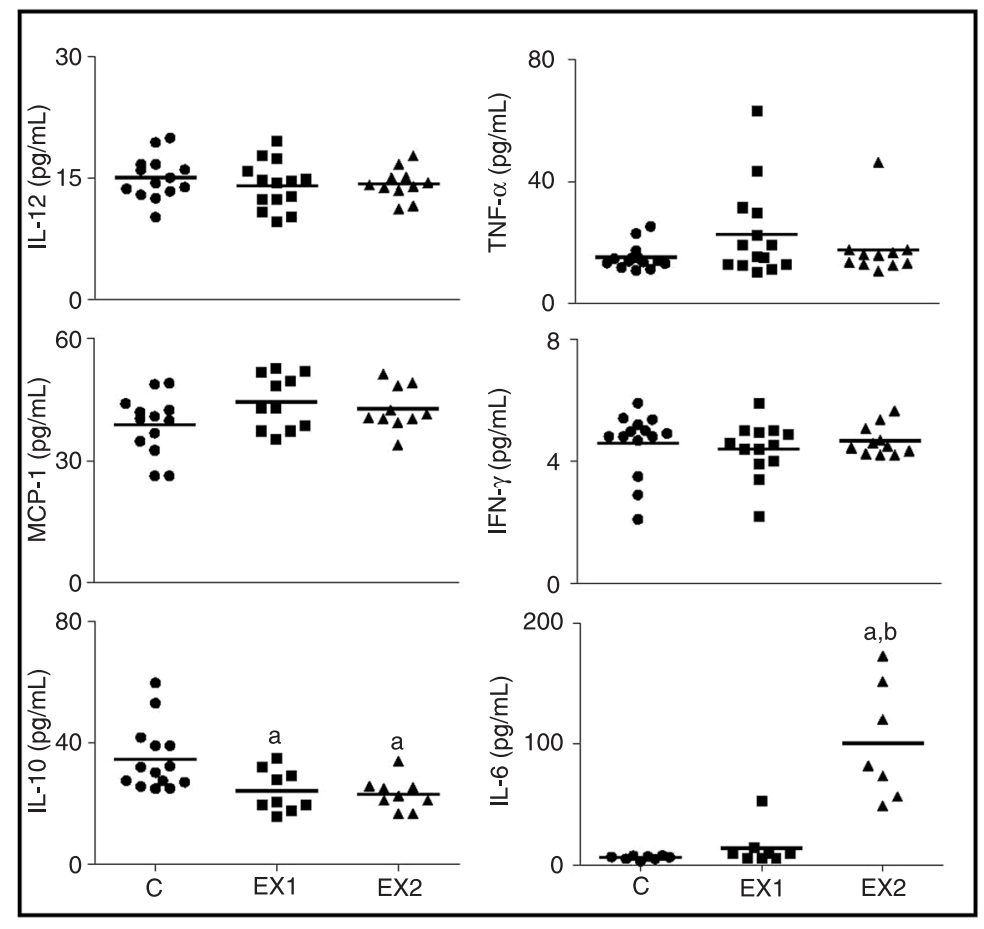

Figure 3. Plasma cytokine profile of non-exercised control mice (C), and of exercised mice immediately after (EX1) and $3 \mathrm{~h}$ following exercise (EX2). aP $<0.05$ compared to control; bP $<0.05$ compared to EX1 (one-way ANOVA). Data from two independent experiments were grouped and are presented. The horizontal lines represent the group medians. 


\section{Discussion}

We observed lipid peroxidation and NF-KB activation in soleus muscle, accompanied by increased plasma levels of IL-6 and reduced levels of IL-10, following a single bout of maximum swimming.

Studies have reported that exercise induces oxidative stress in various tissues, including skeletal muscle. An increased level of lipid peroxidation is the evidence most frequently cited to demonstrate the presence of oxidative stress in various tissues (28). We demonstrated that swimming induced an increase in TBARS generation in soleus muscle immediately after exercise, with this value returning to pre-exercise levels $3 \mathrm{~h}$ later (Figure 1). Davies et al. (29) have shown that exhaustive exercise induces a 2- to 3-fold increase in free radical concentrations in muscle and liver, accompanied by a significant increase in TBARS. Accordingly, Prigol et al. (5) have also observed TBARS in the skeletal muscle of mice $1 \mathrm{~h}$ after a 20-min swimming session. Our results suggest that soleus muscle is directly exposed to oxidative stress during continuous swimming, but that this is a transitory stress, as indicated by pre-exercise (control) TBARS levels $3 \mathrm{~h}$ after exercise.

Many reports have suggested that ROS produced during contractile muscle activity may be responsible for activating signaling pathways, which could culminate with adaptation to exercise. One of these is the NF-KB signaling pathway. $\mathrm{NF}-\mathrm{KB}$ activation in response to muscle contractile activity was first demonstrated by Ji et al. (6). Valdés et al. (13) have also demonstrated NF-kB activation after depolarization of skeletal muscle cells, which can be partially blocked by $\mathrm{N}$-acetyl-L-cysteine, a general antioxidant, indicating the participation of ROS in NF-KB activation in skeletal muscle. This is the first time that NF-kB activation in skeletal muscle in response to swimming has been demonstrated, supporting the idea that the contractile activity is directly responsible for NF-kB activation.

Cytokine secretion in response to exercise has been widely described using experimental models and humans. IL-6 appears to be the cytokine most consistently elevated in response to exercise $(16,17)$. Pedersen and HoffmanGoetz (18) suggested that IL-6 values peak at the end of a strenuous bout of exercise, or within a few hours, and then decrease rapidly to baseline levels. In the present study, we have shown a 16-fold increase in IL-6 secretion $3 \mathrm{~h}$ following swimming (Figure 3), similar to other reports $(14,30)$.

In contrast to data on IL-6, results related to the response of plasma IL-10 to exercise are not consistent. Many investigators have reported no effect of exercise on IL-10 secretion (15,31), while others have observed increased plasma IL-10 levels following exercise $(17,32)$. Similar to the present study, Brenner et al. (22) have described a reduction in plasma IL-10 levels following "all-out" cycling (5 min, $90 \%$ of $\mathrm{VO}_{2 \text { max }}$ ), supporting the concept that the pattern and magnitude of the IL-10 response vary with exercise intensity and duration.

With regard to TNF- $\alpha$, a number of researchers have reported significant increases, albeit modest, in response to strenuous, aerobically biased exercise $(16,33)$. However, in agreement with the present study, others have reported no change in TNF- $\alpha$ levels (17).

A few studies have evaluated the effect of exercise on MCP-1 $(15,34,35)$ but all have observed increased MCP-1 levels in response to exercise, in contrast to the observations of the present study. Also, studies are scarce concerning the effect of exercise on IFN-y and IL-12, two proinflammatory cytokines. To date, only Kimura et al. (36) and Suzuki et al. (37) have investigated the effect of exercise on IFN-ץ; similar to the present study, both have reported no effect of exercise on IFN-y levels. In contrast to our findings, Cox et al. (38) observed reduced IL-12 levels, while Peake et al. (15) reported an increase of this cytokine after exercise.

A number of factors could account for the differing results of the present study and other studies, including the timing of blood sampling, exercise intensity and duration and the type of exercise performed. Paulsen et al. (34) have reported increased MCP-1 levels only $6 \mathrm{~h}$ post-exercise. Considering exercise intensity, Cox et al. (38) reported reduced IL-12 levels in response to maximum exercise, while increased IL-12 levels were observed following high-intensity/longduration exercise (15).

It is well known that different forms of exercise result in different levels of physiologic and adaptive responses. We have chosen to investigate swimming exercise because rodents have a natural ability to swim. Different from treadmill exercise, when previous exercise sessions are necessary for mice to learn how to run, training is not required in swimming. One problem implicated in the "learning" sessions is physiological adaptation to exercise before the experimental session. Using swimming as the exercise paradigm allowed us to evaluate only the acute effects of exercise.

The major drawback of using treadmill exercise is the use of aversive stimuli to encourage running. Many treadmill systems use electric shock to address this question, a procedure that can affect many physiological variables, such as hormone and cytokine secretion, that are evaluated in response to the experimental exercise session. Also, during treadmill running, fatigue is difficult to accurately determine unless some aversive stimulus is employed. However, mice are assumed to be highly motivated to avoid drowning when fatigue is imminent, assuring a high level of performance (24).

Swimming may result in animal stress. In an attempt to minimize this effect, mice from the three experimental groups were adapted to the aquatic environment for 5 days, 10 min a day, before the experimental exercise. Also, during the experimental session, control mice were kept in contact with water in order to mimic the stress of water contact of the exercise groups. No difference in NF-KB activation was observed between the control group employed in this 
study and another one, with no water contact (cage control) (data not shown), indicating that the results observed can be attributed to exercise per se and not to the stress of contact with water.

In addition, experiments investigating swimming require a less expensive apparatus than treadmill running. Therefore, in mice, the swimming system potentially offers advantages compared to treadmill-based types of exercise.

Maximum swimming exercise leads to lipid peroxidation and NF-KB activation in skeletal muscle, as well as IL-6

\section{References}

1. Blair SN, Cheng Y, Holder JS. Is physical activity or physical fitness more important in defining health benefits? Med Sci Sports Exerc 2001; 33: S379-S399.

2. Jolliffe JA, Rees K, Taylor RS, Thompson D, Oldridge N, Ebrahim S. Exercise-based rehabilitation for coronary heart disease. Cochrane Database Syst Rev 2001; CD001800.

3. Piepoli MF, Davos C, Francis DP, Coats AJ. Exercise training meta-analysis of trials in patients with chronic heart failure (ExTraMATCH). BMJ 2004; 328: 189-195.

4. Veskoukis AS, Nikolaidis MG, Kyparos A, Kokkinos D, Nepka C, Barbanis S, et al. Effects of xanthine oxidase inhibition on oxidative stress and swimming performance in rats. Appl Physiol Nutr Metab 2008; 33: 1140-1154.

5. Prigol M, Luchese C, Nogueira CW. Antioxidant effect of diphenyl diselenide on oxidative stress caused by acute physical exercise in skeletal muscle and lungs of mice. Cell Biochem Funct 2009; 27: 216-222.

6. Ji LL, Gomez-Cabrera MC, Steinhafel N, Vina J. Acute exercise activates nuclear factor (NF)-kappaB signaling pathway in rat skeletal muscle. FASEB J 2004; 18: 1499-1506.

7. Ji LL, Gomez-Cabrera MC, Vina J. Role of nuclear factor kappaB and mitogen-activated protein kinase signaling in exercise-induced antioxidant enzyme adaptation. Appl Physiol Nutr Metab 2007; 32: 930-935.

8. Xie QW, Kashiwabara Y, Nathan C. Role of transcription factor NF-kappa B/Rel in induction of nitric oxide synthase. J Biol Chem 1994; 269: 4705-4708.

9. Luo G, Hershko DD, Robb BW, Wray CJ, Hasselgren PO. IL1 beta stimulates IL- 6 production in cultured skeletal muscle cells through activation of MAP kinase signaling pathway and NF-kappa B. Am J Physiol Regul Integr Comp Physiol 2003; 284: R1249-R1254.

10. Pan J, McEver RP. Regulation of the human P-selectin promoter by $\mathrm{Bcl}-3$ and specific homodimeric members of the NF-kappa B/Rel family. J Biol Chem 1995; 270: 23077 23083.

11. Kamata H, Manabe T, Oka S, Kamata K, Hirata H. Hydrogen peroxide activates IkappaB kinases through phosphorylation of serine residues in the activation loops. FEBS Lett 2002; 519: 231-237.

12. Oka S, Kamata H, Kamata K, Yagisawa H, Hirata H. N-acetylcysteine suppresses TNF-induced NF-kappaB activation through inhibition of IkappaB kinases. FEBS Lett 2000; 472: 196-202.

13. Valdés JA, Hidalgo J, Galaz JL, Puentes N, Silva M, Jaimovich $\mathrm{E}$, et al. NF-kappaB activation by depolarization secretion, similar to patterns observed elsewhere. However, exercise resulted in reduced IL-10 levels but did not affect TNF- $\alpha$, MCP-1, IFN- $\gamma$, or IL-12 levels, a fact that can be attributed to both exercise type and intensity.

\section{Acknowledgments}

Research and publication costs supported by FAPEMIG (\#CDS APQ-4263-5.01/07 and PRI-00015-11).

of skeletal muscle cells depends on ryanodine and IP3 receptor-mediated calcium signals. Am J Physiol Cell Physiol 2007; 292: C1960-C1970.

14. Colbert LH, Davis JM, Essig DA, Ghaffar A, Mayer EP. Tissue expression and plasma concentrations of TNFalpha, IL-1beta, and IL-6 following treadmill exercise in mice. Int $\mathrm{J}$ Sports Med 2001; 22: 261-267.

15. Peake JM, Suzuki K, Hordern M, Wilson G, Nosaka K, Coombes JS. Plasma cytokine changes in relation to exercise intensity and muscle damage. Eur J Appl Physiol 2005; 95: 514-521.

16. Ostrowski K, Hermann C, Bangash A, Schjerling P, Nielsen $\mathrm{JN}$, Pedersen BK. A trauma-like elevation of plasma cytokines in humans in response to treadmill running. $J$ Physiol 1998; 513 (Part 3): 889-894.

17. Suzuki K, Yamada M, Kurakake S, Okamura N, Yamaya K, Liu Q, et al. Circulating cytokines and hormones with immunosuppressive but neutrophil-priming potentials rise after endurance exercise in humans. Eur J Appl Physiol 2000; 81: 281-287.

18. Pedersen BK, Hoffman-Goetz L. Exercise and the immune system: regulation, integration, and adaptation. Physiol Rev 2000; 80: 1055-1081.

19. Petersen AM, Pedersen BK. The role of IL-6 in mediating the anti-inflammatory effects of exercise. J Physiol Pharmacol 2006; 57 (Suppl 10): 43-51.

20. Febbraio MA, Pedersen BK. Muscle-derived interleukin-6: mechanisms for activation and possible biological roles. FASEB J 2002; 16: 1335-1347.

21. Durham WJ, Li YP, Gerken E, Farid M, Arbogast S, Wolfe $\mathrm{RR}$, et al. Fatiguing exercise reduces DNA binding activity of NF-kappaB in skeletal muscle nuclei. J Appl Physiol 2004; 97: 1740-1745.

22. Brenner IK, Natale VM, Vasiliou P, Moldoveanu AI, Shek PN, Shephard RJ. Impact of three different types of exercise on components of the inflammatory response. Eur J Appl Physiol Occup Physiol 1999; 80: 452-460.

23. Kaplan ML, Cheslow Y, Vikstrom K, Malhotra A, Geenen DL, Nakouzi A, et al. Cardiac adaptations to chronic exercise in mice. Am J Physiol 1994; 267: H1167-H1173.

24. Dawson CA, Horvath SM. Swimming in small laboratory animals. Med Sci Sports 1970; 2: 51-78.

25. Guide for the care and use of laboratory animals. 8th edn. http://www.nap.edu/catalog/12910.html. Accessed March 5, 2011.

26. Ohkawa H, Ohishi N, Yagi K. Assay for lipid peroxides in 
animal tissues by thiobarbituric acid reaction. Anal Biochem 1979; 95: 351-358.

27. Souza DG, Amaral FA, Fagundes CT, Coelho FM, Arantes $\mathrm{RM}$, Sousa LP, et al. The long pentraxin PTX3 is crucial for tissue inflammation after intestinal ischemia and reperfusion in mice. Am J Pathol 2009; 174: 1309-1318.

28. Liu J, Mori A. Involvement of reactive oxygen species in emotional stress: a hypothesis based on the immobilization stress-induced oxidative damage and antioxidant defense changes in rat brain, and the effect of antioxidant treatment with reduced glutathione. Int J Stress Manag 1994; 1: 249263.

29. Davies KJ, Quintanilha AT, Brooks GA, Packer L. Free radicals and tissue damage produced by exercise. Biochem Biophys Res Commun 1982; 107: 1198-1205.

30. Yu M, Blomstrand E, Chibalin AV, Krook A, Zierath JR. Marathon running increases ERK1/2 and p38 MAP kinase signalling to downstream targets in human skeletal muscle. J Physiol 2001; 536: 273-282.

31. Malm C, Sjodin TL, Sjoberg B, Lenkei R, Renstrom P, Lundberg IE, et al. Leukocytes, cytokines, growth factors and hormones in human skeletal muscle and blood after uphill or downhill running. J Physiol 2004; 556: 983-1000.

32. Rhind SG, Gannon GA, Shephard RJ, Shek PN. Indomethacin modulates circulating cytokine responses to strenuous exercise in humans. Cytokine 2002; 19: 153-158.
33. Sprenger $H$, Jacobs $C$, Nain $M$, Gressner AM, Prinz $H$, Wesemann W, et al. Enhanced release of cytokines, interleukin-2 receptors, and neopterin after long-distance running. Clin Immunol Immunopathol 1992; 63: 188-195.

34. Paulsen G, Benestad HB, Strom-Gundersen I, Morkrid L, Lappegard KT, Raastad T. Delayed leukocytosis and cytokine response to high-force eccentric exercise. Med Sci Sports Exerc 2005; 37: 1877-1883.

35. Nieman DC, Henson DA, Davis JM, Dumke CL, Gross SJ, Jenkins DP, et al. Quercetin ingestion does not alter cytokine changes in athletes competing in the Western States Endurance Run. J Interferon Cytokine Res 2007; 27: 1003-1011.

36. Kimura H, Suzui M, Nagao F, Matsumoto K. Highly sensitive determination of plasma cytokines by time-resolved fluoroimmunoassay; effect of bicycle exercise on plasma level of interleukin-1 alpha (IL-1 alpha), tumor necrosis factor alpha (TNF alpha), and interferon gamma (IFN gamma). Anal Sci 2001; 17: 593-597.

37. Suzuki K, Nakaji S, Yamada M, Totsuka M, Sato K, Sugawara K. Systemic inflammatory response to exhaustive exercise. Cytokine kinetics. Exerc Immunol Rev 2002; 8: 6-48.

38. Cox AJ, Pyne DB, Saunders PU, Callister R, Gleeson M. Cytokine responses to treadmill running in healthy and illness-prone athletes. Med Sci Sports Exerc 2007; 39: 19181926. 